\title{
Section 35 Legal Framework: Implications for Evaluation
}

\author{
Pamela McCurry \\ Carleton University
}

\begin{abstract}
Developments in Canada's constitutional and legal framework since 1982 set the stage for the current Liberal government's nation-to-nation policy, which recognizes Indigenous rights and seeks to build a relationship of respect and partnership through reconciliation with Indigenous peoples. These developments have important implications for those engaged in policy and program evaluations who are now called upon-not only by their own professional ethics but by the legal principles flowing from Section 35-to reimagine their approach and work as partners with Indigenous nations based on the recognition of Indigenous rights, reconciliation, and the Crown's duty to act honourably in all of its dealings with Indigenous peoples. There are no off-the-shelf answers for how this can be done. Evaluation professionals will need to be guided by these key legal principles and the progressive view set out in the Liberal government's Principles respecting the Government of Canada's Relationship with Indigenous Peoples.
\end{abstract}

Keywords: evaluation, first peoples, reconciliation, Section 35

Résumé : Lévolution du cadre juridique et constitutionnel canadien depuis 1982 a ouvert la voie aux politiques de lactuel gouvernement libéral pour les relations de nation à nation, qui reconnaissent les droits autochtones et visent à établir une relation fondée sur le respect et le partenariat, par l'intermédiaire de la réconciliation avec les peuples autochtones. Cette évolution a des conséquences importantes pour les personnes qui font de lévaluation de programmes et de politiques et qui doivent maintenant - non seulement par éthique professionnelle, mais aussi pour des raisons juridiques découlant de larticle 35 - revoir leur approche et travailler comme partenaires des nations autochtones, en tenant compte des droits des Autochtones, de la réconciliation et du devoir de la Couronne d'agir de façon honorable dans toutes ses interactions avec des personnes autochtones. Cependant, il n'existe pas de procédure claire décrivant comment cela doit s'accomplir. Les professionnels et professionnelles de lévaluation devront se laisser guider par ces principes juridiques clés et l'approche progressive décrite dans le document Principes régissant la relation $d u$ Gouvernement du Canada avec les peuples autochtones du gouvernement libéral.

Mots clé : évaluation, Premiers peuples, réconciliation, article 35

Corresponding Author: Pamela McCurry, School of Public Policy \& Administration, Carleton University, 1125 Colonel By Drive, Ottawa, ON, K1S 5B6; pamelamccurry2@ outlook.com 
Canada's Indigenous peoples are distinct peoples. They were here first, and they lived in communities/nations that governed their own people, their lands, and their resources according to their own cultural norms and legal traditions. The colonial objective was to take that power away, and, in practical terms and over time, it succeeded. But the 1982 introduction of Section 35 in Canada's Constitution acknowledged that underlying Indigenous rights were not extinguished. Over the intervening 40 years, the Courts have filled a policy vacuum by giving meaning to Indigenous rights and constructing the essential scaffolding upon which the Crown's relationship with Canada's Indigenous people rests. The current Liberal government's nation-to-nation policy position is built on that and is informed by The Royal Commission on Aboriginal Peoples (RCAP, 1996), the United Nations Declaration on the Rights of Indigenous Peoples (UN Office of the High Commissioner for Human Rights [UNOHCHR], 2013), and the Truth and Reconciliation Commission Report (TRC, 2016). It represents a transformational shift from policy "denial" to clear "recognition" of Indigenous rights, including the right to self-determination, and a focus on building a relationship of respect and partnership through ongoing reconciliation. This is a significant transition that has important implications for those engaged in policy and program evaluations.

\section{FROM SHARED POWER TO CROWN CONTROL AND BACK TO SHARED POWER: FROM TREATIES TO S. 91(24) TO THE PROMISE OF S.35}

By the time Canada's Constitution came into force in 1867, the Crown-Indigenous relationship had already evolved from one of recognition and "peace and friendship" to one marked by efforts to transfer Indigenous rights and power to the Crown through land cession and other means targeted at undermining Indigenous cultures and societies. The journey from the Royal Proclamation, 1763 (which recognized that Indigenous peoples had occupied land prior to European contact and committed to achieving the cession of that land through treaties) to the pre-Confederation treaties, including the Peace and Friendship treaties signed in the Atlantic colonies, the Robinson-Huron treaties, and early land cession treaties in what is now Ontario, showed that colonialist interests had shifted. In the early years, alliances with Indigenous peoples were needed to ensure settler survival. As time passed and focus turned toward settler migration to the west, the primary objective was to ensure the availability of land. The treaties signed between 1871 and 1923 operated to reduce the land base held by Indigenous peoples. Control over "Indians" and their lands was seen as a matter related to Canada's "nation building," and, through Section 91(24), the federal government obtained jurisdiction over "Indians and lands reserved for Indians."

Initially, the jurisprudence took a very narrow view of Indigenous rights. The earliest interpretation of the Royal Proclamation of 1763 was that Aboriginal title was a "personal and usufructory right," which acted as a burden on the Crown's underlying title. The source of Indigenous rights was the Crown's sovereignty. In 
other words, those rights existed at the Crown's discretion (St. Catharines Milling and Lumber Company v. The Queen, 1888).

Under the authority of s. 91(24), the federal government enacted the Indian Act, which created a "wardship" system, controlling the lives of Indigenous peoples from cradle to grave. It created the land reserve system and related band system, dictating the features of governance and controlling all aspects of Indigenous societies, from membership to movement and beyond. While traditional Indigenous governments were not expressly abolished, those who continued to exercise their inherent right to self-government often did so covertly (Centre for First Nations Governance, 2011). There was a prohibition against pursuing land claims, and Indigenous social and spiritual practices were outlawed until the 1950 (Centre for First Nations Governance, 2011). Residential Schools, which operated from the 1800s through to the mid-1990s, were created with the express purpose of taking the Indian out of the child.

The Crown's predisposition to interpreting claimed rights in line with its own interests and legal construct largely denied the Indigenous point of view. Cumulatively and over time, these attitudes and practices buttressed Crown control and manifested a colonialist view that led to the widespread marginalization of Indigenous peoples.

But Indigenous peoples did not give up on their rights, cultures, and nations. Largely as a result of their unrelenting commitment and mobilization, we have observed a mix of significant policy and jurisprudential developments occurring over the last half of the twentieth century and into the twenty-first that have dramatically changed how their place in the country is regarded by Canadians.

\section{A modern legal framework: Section 35}

By 1970, Indigenous peoples were energized by their effective opposition to the federal government's 1969 White Paper (which called for the repeal of the Indian Act and a strategy of assimilation) and by their success in establishing Indigenous title as a legal right to land, not having as its source Crown sovereignty but preexisting it ${ }^{1}$ (Calder v. British Columbia (Attorney General), 1973). Indigenous leaders secured the inclusion of Section 35 in the 1982 amendments to the Constitution, which was a critical turning point in Canadian history, although not obvious at the time.

Section 35 (1) reads, "The existing Aboriginal and treaty rights of the Aboriginal peoples of Canada are hereby recognized and affirmed." 2 This wording is broad, and it was to be the work of Constitutional conferences to settle its meaning. Unfortunately, those conferences failed to close the deep and wide gap between the differing perspectives held by the Indigenous and non-Indigenous negotiators. Indigenous leaders regarded s. 35(1) as a "full box" of rights that would be used to redefine their place in Canada. Non-Indigenous leaders saw it as an "empty box", more symbolism than substance, changing nothing.

Indigenous peoples returned to the courts, and the courts responded in an iterative but highly significant way, creating a constitutional legal framework 
based on s. 35 that has fundamentally redefined the Crown's relationship with Indigenous peoples. It is a framework that will continue to evolve over time but, at its core, recognizes that Indigenous peoples have collective rights derived from their ancestors' presence prior to the assertion of Crown sovereignty and that those rights include the inherent right to govern themselves in relation to those rights (R. v. Van der Peet, 1996; Delgamuukw v. British Columbia, 1997; Tsilhqot'in Nation v. British Columbia, 2014). It recognizes that the inclusion of s. 35 in the Constitution represented "the culmination of a long and difficult struggle in both the political forum and the courts for the constitutional recognition of Aboriginal rights ...." Also, it is guided by s. 35's "call for a just settlement for Indigenous peoples, one that renounces the old rules of the game under which the Crown wielded absolute power to its own advantage"3 (R. v. Sparrow, 1990).

Time and again, the Supreme Court has returned to the core objective of Section 35 both as a means of grounding the interpretation of Indigenous rights and as a means of guiding the conduct of both the Crown and Indigenous peoples within the special relationship they share under the Constitution. The "fundamental objective of the modern law of Aboriginal and treaty rights is the reconciliation of Aboriginal peoples and non-Aboriginal peoples and their respective claims, interests and ambitions." It "provides the constitutional framework through which the fact that Aboriginal peoples lived on the land in distinctive societies, with their own practices, customs and traditions is acknowledged and reconciled with the sovereignty of the Crown" (R. v.Van der Peet, 1996).

The court has advanced this core objective of reconciliation by adopting a progressive vision: it calls for a "purposive analysis" of Section 35(1) to be applied, having regard to a set of general principles that the Court has developed over time and used to characterize the legal relationship between the Crown and Indigenous peoples. The starting point is that the relationship is a fiduciary one. The Court has said that foundational finding demands that a generous and liberal interpretation be given in favour of Indigenous peoples, with any ambiguity as to the scope and definition of s. 35 being resolved in favour of them (R. v. Van der Peet, 1996).

In line with that, when Indigenous rights are assessed based on the tests the courts have developed ${ }^{4}$ (Delgamuuk v. British Columbia, 1997; R. v. Van der Peet, 1996), they can be regarded as occupying a place along a spectrum of rights, from Aboriginal title at one end to rights that are not necessarily connected to the land. And they must be understood using an approach that is culturally inclusive. For example, in the case of Aboriginal title, the Court has said that occupation can be proved by physical presence and Aboriginal law and needs to be evaluated in accordance with the way of life of the people in question (Delgamuukw v. British Columbia, 1997). The approach must take into account the dual perspectives of the Aboriginal group in question (i.e., its laws, practices, size, technological ability) and common-law notions such as, in the case of land and title, possession as a basis for recognition (Tsilhqot'in Nation v. British Columbia, 2014). In support of this balanced approach to the analysis, the Courts have expanded the legal rules of evidence not only to accept the oral histories of Indigenous societies but also to 
place them on an equal footing with other forms of evidence the courts are more accustomed to (Delgamuukw v. British Columbia, 1997). The critical point is that in getting to recognition of a particular Aboriginal right, both sides' views must be respected, as expressed through their own means.

The process of reconciliation begins with this act of recognition that rights exist and continues throughout the relationship. Inherent in the principle of reconciliation is the notion that no rights are absolute. ${ }^{5}$ Thus, at its core, reconciliation demands a principled approach to balancing the rights and interests of Indigenous peoples with the broader Canadian community (Delgamunkw v. British Columbia, 1997, p. 161). Grounded in the fiduciary nature of the relationship, a principled approach to reconciliation means that proposed limits on Indigenous rights must meet a "justification" test. The Crown must demonstrate that the action it proposes to take is "in furtherance of a compelling and substantive objective" and that infringement of the Indigenous right is consistent with the special fiduciary relationship between the Crown and Indigenous peoples (Delgamuukw v. British Columbia, 1997, pp. 161-168). As part of that, the Crown must minimize the impairment of the right and, importantly, consult with the Indigenous group to obtain its perspective. Consistent with the fiduciary relationship, the Crown is held to the standard of acting honourably in this exercise - and in all of its dealings-in order to achieve the reconciliation of pre-existing Indigenous societies with the sovereignty of the Crown.

The court's commitment to the purposes of s. 35 and this principled standard of conduct has been tested, particularly in the regulatory context, by governments that, still influenced by pre-Section 35 norms, have often taken a technocratic and minimalist rather than progressive or purposive approach to their dealings with Indigenous peoples. The courts have responded with increasingly clear direction.

For example, in its 2004 decision in Haida (Haida Nation v. British Columbia (Minister of Forests), 2004) the Supreme Court articulated the principle of the honour of the Crown which has emerged as the primary standard for both guiding and assessing Crown conduct in managing its relationships with Indigenous peoples. The Court identified the honour of the Crown, otherwise put, the Crown's responsibility to act honourably, as the source of the duty to consult with Indigenous peoples and to accommodate those rights, where appropriate. The duty arises when the Crown contemplates taking action that may have an impact on claimed Indigenous rights. The practical parameters of the duty to consult and accommodate depends on the strength of the claim and potential impact of Crown actions on it. ${ }^{6}$

This was a significant and foundational decision. It introduced the idea of general recognition of Indigenous rights, which do not have to be "proved" or established by a court in order to command acknowledgement and respect. And it gave heft to the Crown's duty to act honourably in all its dealings with Indigenous peoples. That includes a duty to engage respectfully with Indigenous peoples and give full account to their perspectives. This has been the Court's way of saying that it's all about the relationship. 
The Court's careful articulation of the principles of reconciliation, the fiduciary relationship, the honour of the Crown, and the duty to consult has provided the Crown and Indigenous peoples with a range of tools to respectfully and constructively manage their relationships. Aligned with that, the Court has repeatedly encouraged principled processes of honourable negotiation over reliance on the courts to resolve differences. It is "only through negotiations with good faith and give and take on all sides, reinforced by the judgments of the court, that we will achieve what is said to be the basic purpose of section 35 (i.e., the reconciliation of the pre-existing Aboriginal societies with the sovereignty of the Crown). Let us face it. We are all here to stay" (Delgamuukw v. British Columbia, 1997, p. 181).

\section{THE GOVERNMENT POLICY AGENDA: NATION TO NATION}

The federal government's nation-to-nation agenda, as expressed in the Principles respecting the Government of Canada's Relationship with Indigenous Peoples (Minister of Justice, 2017) rests on this legal and constitutional framework. It advances an ambitious and progressive view that is founded on the promise of Section 35 and informed by RCAP, the TRC, and UNDRIP.

Prime Minister Justin Trudeau, saying that the Crown-Indigenous relationship reflects a sacred obligation founded on constitutionally protected Indigenous rights, has called for a renewed nation-to-nation relationship, "based on recognition of rights, respect, co-operation, and partnership" (Trudeau, 2015). The Principles say that the promise of s. 35 and UNDRIP's call to respect and promote the inherent rights of Indigenous peoples mean that all governments should "shift their relationships and arrangements with Indigenous peoples so that they are based on recognition and respect for their rights to self-determination, including the inherent right to self-government for Indigenous nations" (Minister of Justice, 2017) (Principle 1). In other words, recognition of these rights is at the heart of reconciliation, and in order to give life to a new post-colonialist relationship we must build new structures and make decisions in new ways. We must move from control to collaboration (Webber, 2017).

The principle of reconciliation under Section 35, with its objective of restoring mutually respectful relations between peoples and nations, is large enough to accommodate all of that. In fact, it demands it. And the Court reminds us that what it looks like in practice "must be devised by means that are more participatory, cross-cultural, flexible and varied than are possible in proceeding before the courts"9 (Webber, 2017). What we are looking for is institutional mechanisms that are accepted as legitimate by all constituent groups and are capable of working together ${ }^{10}$ (Webber, 2017). Both Indigenous nations and governments must work at this across the range of their many interactions.

\section{MAKING THE NATION-TO-NATION RELATIONSHIP A REALITY}

Progress toward turning the "nation-to-nation" vision into a reality remains slow and tentative because many of the key structural impediments, including biases, 
have remained intact. Nonetheless, the steps the federal government has taken may be seen as progress toward establishing the conditions within which Indigenous peoples can resituate themselves by rebuilding their nations and reassuming their role as full partners in the country's constitutional order. A critical next step will involve Indigenous leaders and the federal government working together, on a nation-to-nation basis, to develop shared understandings of what Indigenous "self-government," "nationhood," and "co-existing sovereignties" mean. It is through this collaborative effort that the terms upon which-and the institutional arrangements through which-ongoing nation-to-nation relationships can be developed and maintained. Evaluation professionals should be both keen observers of and participants in these efforts, which will necessarily reshape and enrich both their work processes and the value of their contributions to making the nationto-nation relationship a reality. Along the way, Canada's constitutional framework will continue to evolve as the courts are called upon to provide further guidance.

For their part, Indigenous leaders will necessarily lead the work of nation building. Stephen Cornell, a specialist in political economy and cultural sociology and co-founder of the Harvard Project on American Indian Economic Development, has spent decades working closely with Indigenous nations and organizations in the United States, Canada, Australia, and New Zealand, on governance, economic development, and tribal policy issues to help them do just that. Cornell (2008) encourages Indigenous leaders to dedicate themselves to rebuilding the fundamentals, that is, identifying their citizenry, developing independent governments and independent economic institutions, and securing territory and sources of revenue. He underscores the magnitude of the challenge that Indigenous leaders face in this work, acknowledging that they will have to look after present social, economic, cultural, and other needs of their people (for example, housing, education, social services, water) while building toward a future in which their nation's relationships with other orders of government are put on a fundamentally different footing.

This is highly complex work that engages challenges on three broad fronts: political, fiscal, and administrative. For example, while the legal and constitutional framework is in place, the political challenges Indigenous leaders face are both internal to the community (e.g., community readiness, will and resilience, confidence and trust) and external (securing willing and committed partners in other orders of government). The fiscal challenges include breaking out of structural obstacles in the existing model and finding sources of funding for rebuilding governance, while constructing new fiscal relationships with other orders of government. And the administrative challenges are equally fundamental and daunting. Indigenous leaders must realign their nation's administration and help it develop the new tools needed to support and implement new models and political directions.

Cornell (2018) argues that at the core of this nation rebuilding is the task of building good governance (i.e., how the community organizes itself to pursue its own objectives, through "sustained, effective, organized action today"). He describes three major elements that should be dealt with by communities as priorities. 
First, the community should identify its core principles (i.e., the fundamental understandings of the community that come out of its own experience and culture that reflect what the community is about, what its purposes are, the basis of authority in the community, and the appropriate organizational use of that authority). And it should define what the community is trying to protect, change, and achieve. It should then use those core principles to guide the building of practical, effective mechanisms and robust tools (such as written constitutions, designated offices, laws, and the mechanisms for enforcing those laws), agreements with other governments, and a range of other practical tools, including evaluation, that will form the machinery that gets things done on a daily basis.

Second, the community must build a bureaucratic administration that is grounded in sound management practices and is capable of supporting political decision making, implementing government direction across a range of sectors, and, in line with its values, evaluating progress.

Third, the community must build new relationship mechanisms with other orders of government. With the assumption of jurisdiction in place, these will be the mechanisms through which Indigenous nations can negotiate the spheres within which they will operate, and related issues of subsidiarity, and the support they need to manage a broad range of social needs while sorting out critical issues of lands, resources, and fiscal arrangements on both a transitional and ongoing basis. ${ }^{11}$ These will also be the mechanisms through which Indigenous governments working collaboratively with other orders of government can evaluate the success of their efforts.

Similarly, guided by the legal and constitutional principles that are part of what is required by Section 35, recognition of rights, reconciliation, and the duty to act honourably, and in line with the commitments articulated in the Principles respecting the Government of Canada's Relationship with Indigenous Peoples, the federal government will need to strengthen its own capacity to respect and accommodate Indigenous nations' core principles, constitutions and laws, agreements, and other tools; adjust its own bureaucratic administration; and be a willing and committed partner in the co-development of mechanisms that will effectively support the nation-to-nation relationship in both the immediate and long terms.

\section{WHAT DOES THIS MEAN FOR POLICY AND PROGRAM EVALUATION?}

The evaluation function is part of the apparatus through which non-Indigenous governments engage with Indigenous peoples. While there is a notable and developing history of Indigenous evaluation professionals who continue to engage effectively with Indigenous communities, in general, relationships have suffered from the same structural impediments and pre-Section 35 biases that have slowed the country's progress toward making the nation to nation vision overall. But that must change. The legal and constitutional framework developed by the courts since the introduction of s. 35 of the Constitution makes it clear that non-Indigenous governments must work as partners with Indigenous nations 
based on recognition of Indigenous rights, reconciliation, and the Crown's duty to act honourably in all of its dealings with Indigenous peoples. If the evaluation function is to remain truly effective in supporting both non-Indigenous and Indigenous governments in working together on the basis of these constitutional principles, evaluations professionals must find ways of reflecting those principles in their work as well. The question is, however, how the field can move forward to accomplish this. How will it change the approach to evaluation in practical terms?

To begin, and at the broadest level, evaluation professionals may wish to consider three questions. First, in light of the Section 35 legal framework, how can evaluation models accommodate the fact of co-existing sovereignties? How will objectives be articulated, and responsibilities and accountabilities sorted out? Second, what is important to an Indigenous nation as a measure of success may be different from what is important to another order of government. The same may be true of what is considered "valid evidence," including questions of what knowledge can and should be gathered, and how it should be gathered and communicated. What steps can be taken to ensure that evaluation models respectfully and substantively reflect Indigenous cultures, traditions, and laws? And finally, how can evaluation professionals develop a strategy that will help them do their jobs through what will, inevitably, be a long transition period as Indigenous nations rebuild? How can these professionals prepare themselves to respond to the variety of forms that nation building will take and the varying timelines within which it will occur?

Unfortunately, there are no clear, cookie-cutter or "off-the-shelf” answers or evaluation models to offer. The nation-to-nation agenda is transformative and without precedent. It is about decolonization and making self-determination and self-government for Indigenous peoples real in the twenty-first century. It is "a project of disorder," not mild adjustment (Cram, 2018), and it is-at its very core-a project of co-creation with non-Indigenous and Indigenous governments working together. It is thus inherently difficult, and it will take time.

Evaluation professionals can prepare themselves to support the nation-tonation agenda by looking to the key legal principles flowing from Section 35 and the progressive view of those principles set out in the government's Principles respecting the Government of Canada's Relationship with Indigenous Peoples to be both their guide and their "minimum standard" 12 for evaluations. This will require a fundamental re-think of the purely accountability-focused purposes of governmental evaluations that extend from funding agreements.

It begins by recognizing Indigenous rights, including the rights to selfgovernment and self-determination. This calls for a critical and profound shift in thinking and an acceptance that, in Canada, pre-existing Indigenous sovereignty and Canadian sovereignty must find ways of co-existing (Webber, 2017). Evaluation professionals could then work toward building new relationships and new evaluation models that rest on that foundational reality. For example, advancing the principle of reconciliation would mean committing to deep collaboration that begins with understanding and sharing a commitment to Indigenous objectives 
and continues through a willingness to share knowledge and co-build new frames and tools. Part of acting honourably would mean being transparent about government's expectations and interests and working with Indigenous nations toward a balanced approach that takes both Indigenous and non-Indigenous interests and values into account. It would mean ensuring that evaluation conceptual frameworks/inquiry paradigms are open to the Indigenous worldview, using Indigenous ontological frameworks as guiding evaluation practices. And it would mean demonstrating commitment to realizing the vision of self-determination and self-government by working to strengthen Indigenous capacity.

Taken cumulatively, this goes well beyond thinking about the "cultural responsiveness of methodology." Just as Section 35 and the "nation-to-nation" agenda call for a complete reframing of the government's historic colonialist relationship with Indigenous peoples (Webber, 2017), so also do they call for a complete reframing of the knowledge and methods used in evaluations (Bowman \& Dodge-Francis, 2017).

Bowman's CRIE model (Culturally Responsive Indigenous Evaluation) offers a picture of what the desired "blended" approach might look like. The model sets out the "Western" or non-Indigenous paradigm for what evaluations look like (strength, skills, and capacities; challenges and barriers; gaps and needs; solutions and strategies). It sets out an Indigenous paradigm (relations and community building; using your teachings; humility and balance; visioning and pathfinding). And then it offers what could result by bringing the elements of the two paradigms together into a "blended" or balanced approach. The blended elements would be the following: building community through shared strengths and a strengthsbased approach; using challenges as opportunities to use teachings; addressing needs and gaps by humbly asking for help and restoring balance; and using experiential knowledge to develop evidence-based solutions for a future vision (Bowman \& Dodge-Francis, 2017).

\section{DEMONSTRATING LEADERSHIP}

The recognition of Indigenous communities as self-governing nations, enjoying sovereignty within the Canadian constitutional order, means that the nations will determine their own objectives and the means for achieving those objectives and will be accountable for achieving related results. That is the transformation that Indigenous communities want: decolonization, self-determination, and selfgovernment. Although they will continue to work with other orders of government as partners, the instruments and mechanisms employed will necessarily be adjusted over time in order to accommodate the shared power that will characterize the ongoing reconciliation of Canada's co-existing sovereignties.

Bowman argues that "evaluation should be a tool of transformation, improvement and empowerment" (Bowman \& Dodge-Francis, 2017). But existing evaluation tools have been externally imposed and do not reflect the worldviews, values, and goals of Indigenous peoples. Decolonizing the relationship with Indigenous 
people will require decolonizing evaluation models and frameworks. It is about moving from evaluations that are framed and controlled by non-Indigenous governments to evaluations that are characterized by "collaboration, co-design and capacity building toward the central objective of ensuring that Indigenous evaluations are, ultimately, designed and led by Indigenous people" (Cram, 2018).

The journey will be challenging. Funding governments may at times be intransigent in their focus on their own accountability needs. But the larger constitutional vision for the country is clear, the work is important, and evaluation professionals can welcome this moment of opportunity to support governments in advancing it. Taking that broader view, governments know they need the help. Guided by the legal and constitutional principles of recognition, reconciliation, and the honour of the Crown, as well as by their own professional ethics, evaluation professionals can make an enormous contribution to rebuilding selfdetermining and self-governing Indigenous nations so that those nations can reassume their rightful place in our constitutional order. Achieving that will ensure the survival, dignity, and well-being of Indigenous peoples in Canada (UNOHCHR, 2013).

\section{NOTES}

1 In Calder, the Supreme Court of Canada found that Aboriginal rights, and specifically Aboriginal title, existed in Canada before the Royal Proclamation of 1763, were not derived from colonial law, and had not been extinguished by Crown sovereignty. The federal government had had a policy against negotiating land claims since the 1920s but after Calder it introduced the Comprehensive Claims Policy to deal with land claims. It also introduced the Specific Claims Policy to deal with disputes over land issues and treaty implementation.

2 Part 2 of the Constitution Act, 1982, Schedule B to the Canada Act, 1982 (UK), c.11. Section 35(2) of the Act defines "Aboriginal peoples" as including Inuit and Métis.

3 In Sparrow, making the point that the Crown controlled all the conditions within which Aboriginal rights and interests are judged, the Court noted that the Crown "established courts of law and then denied those courts the authority to question sovereign claims by the Crown."

4 The test for Aboriginal title is evidence that the land was exclusively occupied at the time of the Crown's assertion of sovereignty (Delgamuukw v. British Columbia, 1997). The test for Aboriginal rights apart from title is that the particular activity claimed as a right must relate to a practice, custom, or tradition that was integral to the Aboriginal group's distinctive culture prior to contact with the Europeans (R. v. Van der Peet, 1996).

5 It is also consistent with the approach taken in the Charter of Rights, where individual rights may be subject to reasonable limits in a free and democratic society. See Section 1.

6 The duty to consult is also a procedural requirement in relation to treaty rights (Mikisew Cree First Nation v. Canada (Minister of Heritage), 2005).

7 RCAP meticulously made the legal and policy case for Indigenous rights to selfgovernment and provided extensive recommendations on how recognizing Indigenous nations as a third order of government could work. UNDRIP identifies the rights of 
Indigenous peoples to develop and maintain their own political, economic, and social institutions, including juridical systems (Articles 5, 20 and 34), as among the "minimum standards for the survival, dignity, and well being of the Indigenous peoples of the world" (Article 43). The TRC Report, informed by UNDRIP and adopting its human rights frame, effectively argued for self-government on the same basis and reflected that in its 94 Calls to Action.

8 So far, the Supreme Court has not been faced with a situation that has required it to decide self-government rights, but it is difficult to disagree with those who argue that the Court has implicitly and at a general level recognized the existence of those rights based on its acknowledgement of pre-existing Indigenous societies, cultures, traditions, and laws that help determine the modern existence of other rights that are collective and include control over territory. In fact, the Court has even acknowledged "the preexisting Aboriginal sovereignty, along with Canadian sovereignty, and said that the Aboriginal rights and s. 35 are about the search between societies, each of which is entitled to be included in the Constitutional order" (Webber, 2017, p. 289). Nonetheless, the Court has demonstrated characteristic patience in the belief that these questions and other questions between the parties, both large and small, are best sorted out by the parties (governments) through principled negotiation.

9 The SCC most recently underscored this view in its December 2017 decision in Nacho Nyak Dun First Nation et al v. Government of the Yukon, [2017] 2 S.C.R. 576, commonly referred to as the "Peel Watershed" case.

10 One can argue that, although the process has been painfully slow and discontinuous, at some level, competing views of Indigenous self-government have been in "negotiation" since the mid-1990s. Preceding RCAP and the TRC, the Penner Report and Charlottetown Accord both supported the right to self-government for Indigenous peoples. And the federal government's 1995 Inherent Right Policy, a companion piece to the Comprehensive Claims Policy, set out the parameters within which the federal government has been prepared to negotiate terms of self-government with Indigenous communities.

11 The mechanisms should include dispute-resolution mechanisms that will support good relationships and reduce overall reliance on litigation.

12 A reference to the United Nations Declaration on the Rights of Indigenous Peoples (UNDRIP) Article 43, which highlights the minimum standards required for the survival, dignity, and well-being of the Indigenous peoples of the world.

\section{REFERENCES}

Bowman, N., \& Dodge-Francis, C. (2017). Culturally responsive Indigenous evaluation and tribal governments: Understanding the relationship. Asserting tribal sovereignty in evaluation and policy studies. Retrieved from https://www.ncai.org/policy-researchcenter/initiatives/tribal-leader-scholar-forum

Calder v. British Columbia (Attorney General). SCR 313 (1973).

Centre for First Nations Governance. (2011). A brief history of our right to self-government: Pre-contact to present. Ottawa, ON: Author.

Cornell, S. (2008, October 30). Keynote address to British Columbia Treaty Commission Conference. Vancouver, BC: British Columbia Treaty Commission. Retrieved from http://www.bctreaty.ca/sites/default/files/Dr.\%20Stephen\%20Cornell\%20TranscriptFINAL.pdf 
Cram, F. (2018). Conclusion: Lessons about Indigenous evaluations. New Directions for Evaluations, 2018(159), 121-133. https://doi.org/10.1002/ev.20326

Delgamuukw v. British Columbia. 3 SCR 1010 (1997).

Haida Nation v. British Columbia (Minister of Forests). 3 SCR 511 (2004).

Mikisew Cree First Nation v. Canada (Minister of Canadian Heritage). 3 SCR 388 (2005).

Minister of Justice. (2017). Principles respecting the Government of Canada's relationship with Indigenous peoples. Retrieved from https://www.justice.gc.ca/eng/csj-sjc/ principles-principes.html.

Royal Commission on Aboriginal Peoples. (1996). Final report. G. Erasmus \& and R. Dussault, co-chairs. Ottawa, ON: Author.

R. v. Sparrow. 1 SCR 1075 (1990).

R. v. Van der Peet. 2 SCR 507 (1996).

St. Catharines Milling and Lumber Company v. The Queen. 14 App Cas 46 (1888).

Trudeau, J. (2015). Mandate Letters to Ministers. Retrieved from https://pm.gc.ca

Tsilhqot'in Nation v. British Columbia. 2 SCR 257 (2014).

Truth and Reconciliation Commission of Canada. (2015). Final Report of the Truth and Reconciliation Commission of Canada: Summary: Knowing the truth, reconciling for the future. Winnipeg, MB: Author.

UN Office of the High Commissioner for Human Rights. (2013). Declaration on the Rights of Indigenous Peoples. Retrieved from https://www.refworld.org/docid/5289e4fc4. html

Webber, J. (2017). Contending sovereignties. In P. Oliver, P. Macklem, \& N. Derosier (Eds.), The Oxford handbook of the Canadian constitution (p. 289). New York, NY: Oxford University Press.

\section{AUTHOR INFORMATION}

Pamela McCurry held a variety of senior positions in the federal public service over the course of her 35-year career, including, from 2009, Senior Assistant Deputy Minister, Policy and Strategic Planning at what was then called Indian and Northern Affairs Canada, and Assistant Deputy Attorney General and Assistant Deputy Minister, Aboriginal Affairs, Justice Canada. She has served as a Fellow in Carleton University's School of Public Policy since May 2017. 